\title{
Optimalisasi Production Well Test Untuk Mendukung Performance Produksi Dengan Cara Tiering System Pada Area X Lapangan Y
}

\author{
Novia Rita, Novrianti, Jasril \\ Program Studi Teknik Perminyakan Universitas Islam Riau
}

\begin{abstract}
Abstrak
Area X merupakan salah satu area yang terdapat di Lapangan Y PT. Chevron Pacific Indonesia, dimana area X terdiri dari 563 sumur. Pada Area X ini dilakukan pekerjaan tes terhadap sumur sebanyak 2 kali per bulan, sehingga untuk 563 sumur diperlukan 1126 kali tes perbulan. Fasilitas yang tersedia untuk production well test pada Area X hanya mampu 960 kali tes per bulan. Sehingga 116 sumur tidak akan mendapatkan jadwal tes pada setiap bulannya. Apabila prosedur seperti ini tetap dilakukan secara terus menerus maka akan selalu terdapat sisa sumur yang belum terpenuhi untuk dilakukan tes di setiap bulannya. Untuk mengatasi permasalahan ini dilakukan Tiering system. Tiering system adalah suatu metode dalam proses pengujian sumur dimana dalam metode ini sumur-sumur akan dikelompokkan berdasarkan produksi terbesar hingga terkecil. Sumur yang tergolong big production akan berada pada urutan teratas untuk dilakukan Well Testing (Tier \#1) dan diikuti Tier \#2, Tier \#3 dan Tier \#4 (Tiering System merupakan metode atau proses yang digunakan untuk mengelompokan data-data production well testing sumur yang banyak menjadi kelompok kelompak kecil, yang bertujuan untuk membantu mengoptimalisasi proses pekerjaan well test di Lapangan (Human Resources Sumatra Operation, 2012).. Kuantitas test sumur setiap bulan akan disesuaikan dengan kebutuhan data dan kategori Tier, hal ini bertujuan untuk mendapatkan data yang valid secara continue pada sumur, sehingga cepat diketahui dan di follow up jika terjadi permasalahan penurunan produksi pada sumur-sumur tersebut. Dengan Tiering System, maka 563 sumur yang harus dilakukan well testing setiap bulannya di Area X jadi terpenuhi karena hanya membutuhkan 777 kali tes perbulan. Bahkan waktu pelaksanaan well test masih tersisa untuk 183 kali tes, hal ini juga berdampak pada kenaikan produksi sebesar 5441 bbl per hari dengan keuntungan sebesar 217.621,75 US\$.
\end{abstract}

Kata kunci: Production Well Test, Well Testing, Big Production, Tiering System

\begin{abstract}
Area X is one of the area contained in the Field Y PT. Chevron Pacific Indonesia, where X area consists of 563 wells. In Area $\mathrm{X}$ is performed work on the well test 2 times per month, so the 563 wells required for the test 1126 times per month. Facilities available to production well test in Area X only able to test 960 times per month. So that 116 wells will not get test dates each month. If a procedure such as this are carried out continuously it will always are the remaining unmet wells to be tested every month. To resolve this problem do Tiering system. Tiering system is a method in which the well testing process in this method the wells will be grouped by largest to smallest production. Wells are relatively big production will be at the top to do Well Testing (Tier \# 1), followed by Tier \# 2, Tier \# 3 and Tier \# 4 (Tiering System is a method or process used to categorize the data production well testing wells many become smaller group again group, which aims to help optimize processes work well test in the field (Human Resources Operation Sumatra, 2012) .. the quantity of test wells per month will be tailored to the needs of data and Tier category, it aims to obtain valid data a continuously on the well, so quickly identified and follow-up in case of problems cutting production in these wells. With Tiering System, the 563 wells that must be done well testing every month in Area X be fulfilled because it only requires 777 times tests per month. Even the well test execution time remaining for the test 183 times, this has also resulted in increased production of 5441 bbl per day with a profit of US $\$ 217,621.75$.
\end{abstract}

Keywords: Production Well Test, Well Testing, Big Production, Tiering System

Corresponding author email: noviarita@eng.uir.ac.id

PENDAHULUAN

Production Well Testing adalah suatu pekerjaan atau aktivitas yang dilakukan pada sumur produksi yaitu pengukuran produksi dalam jangka waktu tertentu menggunakan prasarana pengujian untuk 
mengetahui data produksi dari setiap sumur (oil, water dan gas) per hari (Amin, 2013). Data ini penting bagi Petroleum Engineer untuk menganalisis sumur dan formasi secara keseluruhan, apakah sumur tersebut masih berproduksi dengan baik atau memerlukan well service atau workover job untuk mempertahankan atau meningkatkan laju produksi.

Permasalahan yang sering terjadi dalam melakukan production well testing di lapangan yaitu waktu yang sangat terbatas dalam proses aplikasinya, hal ini disebabkan oleh keterbatasan fasilitas test station. Oleh sebab itu untuk melakukan kegiatan production well testing perlu dilakukan manajemen waktu dan pengelompokan terhadap data-data sumur, sehingga mempermudah pekerjaan seorang Petroleum Engineer dalam menanggulangi permasalahan pada setiap sumur ketika terjadi penurunan produksi minyak.

Pada penelitian ini dilakukan analisis mengenai Tiering System terhadap data-data sumur yang akan dilakukan production well testing. Tiering System merupakan metode atau proses yang digunakan untuk mengelompokan data-data production well testing sumur yang banyak menjadi beberapa kelompok, hal ini bertujuan untuk membantu mengoptimalisasi proses pekerjaan well test di Lapangan (Human Resources Sumatra Operation, 2012). Terdapat sekitar 563 sumur yang akan dilakukan well testing di Area X, sehingga perlu dilakukan Tiering System terhadap masing masing sumur berdasarkan produksi oil per hari nya. Setelah Tiering System dilakukan akan dilihat kenaikan Produki pada Area X Lapangan Y ini.

\section{METODOLOGI}

Pada penelitian ini akan dilakukan analisis terhadap sumur-sumur yang berada di area $\mathrm{X}$ pada Lapangan Y. Dimana pada area X ini terdapat 563 sumur yang masih produktif dan yang akan dilakukan rutinitas testing di setiap bulannya. Dalam melakukan Tiering System tahap mula-mula yang harus dilakukan adalah mengelompokan masing masing sumur berdasarkan produksi minyak hariannya. Pengelompokan ini bertujuan untuk menyusun sumur yang memiliki produksi paling tertinggi hingga terendah yang nantinya akan diprioritaskan untuk melakukan testing.

Setelah diperoleh data dalam pengelompokan sumur maka tahap selanjutnya adalah melakukan review dan analisis yang lebih detail terhadap hasil pengelompokan data yang dilakukan. Sehingga dengan mengelompokkan sumur-sumur berdasarkan produksi tertinggi hingga terendah dan review data sumur tersebut maka diperoleh jumlah optimum sumur yang bisa di tes dengan tetap mempertimbangkan pencapaian compliance seoptimal mungkin.

Untuk meminimalkan kehilangan produksi dan mempermudah pengambilan data maka sumur-sumur tersebut dikelompokkan berdasarkan dari total produksi tertinggi hingga terendah. Dari 563 sumur, nantinya akan dikelompokkan menjadi 4 kelompok (Tier\#1, Tier\#2, Tier\#3 dan Tier\#4).

Dengan melakukan analisis statistika maka diperoleh data frekuensi atau jumlah sumur untuk masing masing kategori dikelompokan bedasarkan jumlah produksi minyak terbesar hingga terkecil, hal ini dapat dilihat pada Tabel 1 berikut: 
Tablel 1. Jumlah sumur Terhadap Total Produksi oil perhari

\begin{tabular}{|c|c|c|c|}
\hline No & Produksi (BOPD) & Jumlah sumur & Kelompok \\
\hline 1. & $<10$ & 216 & Tier \#4 \\
\hline 2. & $10-25$. & 184 & Tier \#3 \\
\hline 3. & $25-50$ & 112 & Tier \#2 \\
\hline 4. & $>50$ & 51 & Tier \#1 \\
\hline
\end{tabular}

Untuk selanjutnya pengelompokan berdasarkan tabel diatas disebut sebagai Tier. Dalam melakukan test maka perlu menentukan pilihan terbaik antara jumlah test yang akan dilakukan pada masing masing Tier, sehingga nantinya dapat terpenuhi kapasitas dengan penggunaan fasilitas yang optimal. Berdasarkan diagram dibawah pengelompokan Tier sumur dilakukan berdasarkan parameter produksi dari masing masing sumur yang dibagi berdasarkan kelompok sebagai berikut:

- Tier \# 1 untuk produksi sumur > 50 BOPD ada 51 sumur

- Tier \# 2 untuk produksi sumur 25 - 50 BOPD ada 112 sumur

- Tier \# 3 untuk produksi sumur 10 - 25 BOPD ada 184 sumur

- Tier \# 4 untuk produksi sumur < 10 BOPD ada 216 sumur

Dari pengelompokan data di atas dapat dilihat hasil pengelompokan pada Gambar 1 dan dari hasil tersebut dapat dijabarkan sebagai berikut:

a. Tier \#1 merupakan suatu kategori pengelompokkan sumur yang paling diprioritaskan untuk dilakukan well test dan mempunyai kontribusi yang besar untuk area (40\%). Dari total 563 sumur yang ada di area X terdapat 51 sumur yang berada di Tier \#1 (produksi > 50 BOPD) merupakan kelompok big production sehingga akan diperlukan data berulang-ulang kali untuk memperoleh dan mempertahankan produksi. Dan untuk itu sumur yang termasuk dalam kategori Tier \# 1 maka akan dilakukan well test sebanyak 3 kali test perbulan untuk setiap sumurnya.

b. Tier \#2 merupakan kategori pengelompokkan sumur yang juga diprioritaskan untuk dilakukan well test setelah Tier \#1 (medium priority). Dari total 563 sumur yang ada di area X terdapat 112 sumur yang berada di Tier \#2 (produksi 25-50 BOPD) dan tergolong produksi yang cukup besar sehingga akan dilakukan well test sebanyak 2 kali test perbulan.

c. Tier \#3 merupakan kategori pengelompokkan sumur yang produksinya tergolong rendah yaitu 10-25 BOPD (low priority). Dari total 563 sumur yang ada di area X terdapat 184 sumur yang termasuk dalam Tier \#3. Untuk kategori ini akan dilakukan tes sebanyak 1 kali perbulan untuk setiap sumurnya.

d. Tier \#4 merupakan kategori pengelompokkan sumur yang produksinya sangat rendah yaitu $<10$ BOPD (may not have resources). Dari total 563 sumur yang ada di area X terdapat 216 sumur yang termasuk dalam Tier \#4. Untuk kategori ini akan dilakukan tes sebanyak 1 kali perbulan untuk setiap sumurnya. 


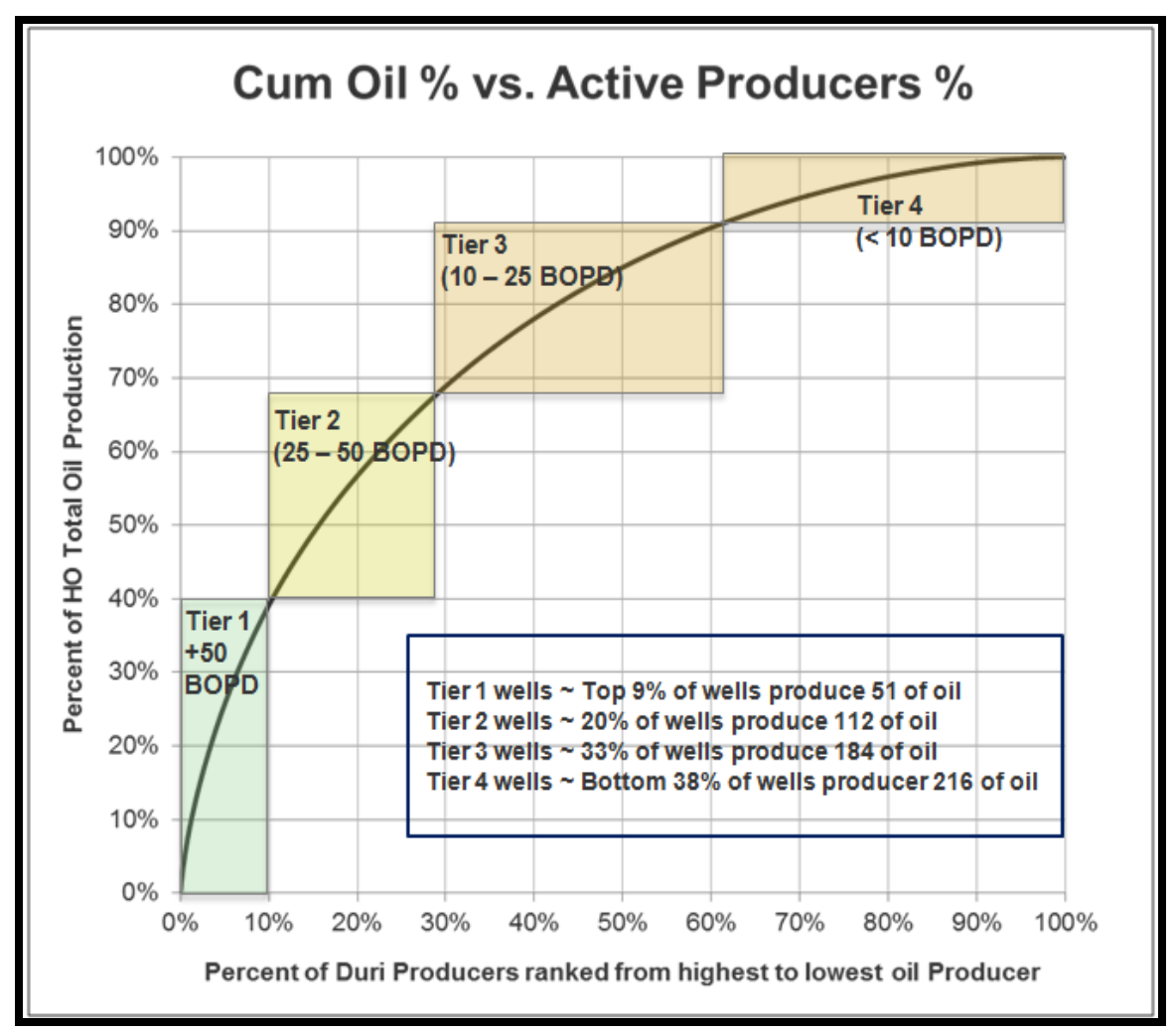

Gambar 1. Persentasi produksi dari nilai terbesar hingga terkecil pada area X

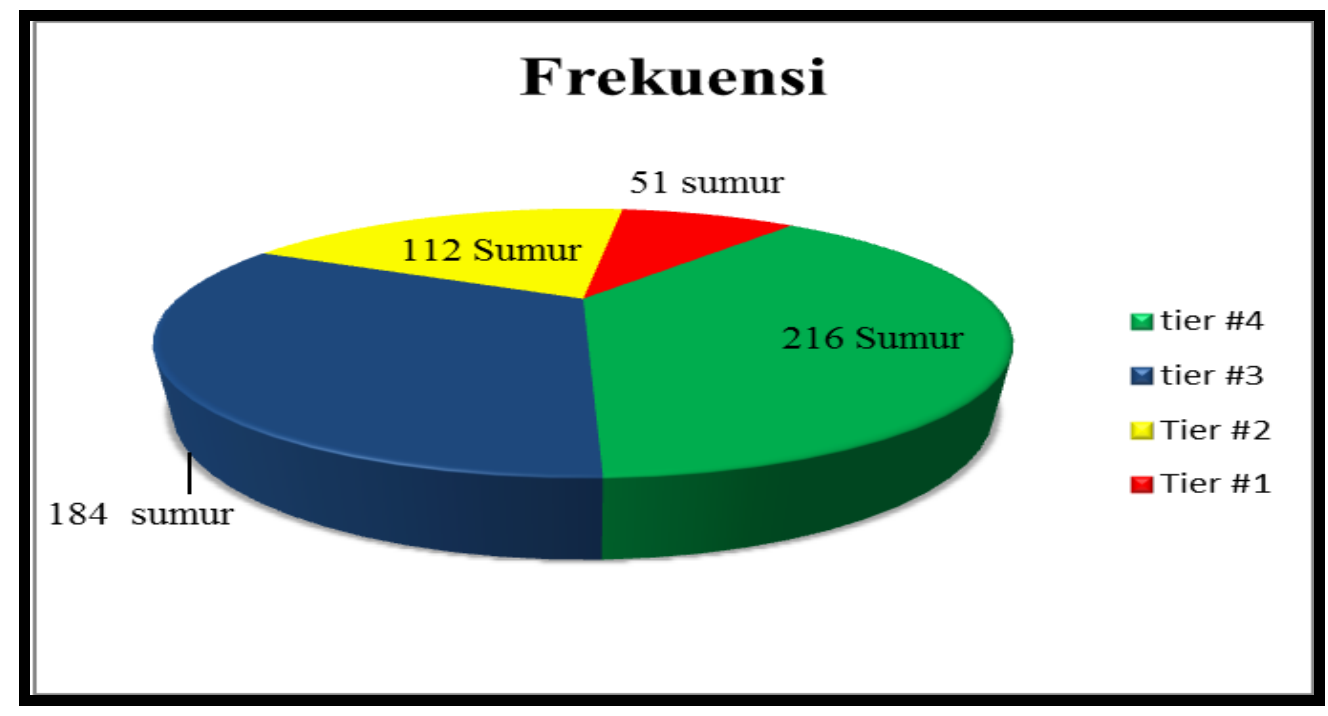

Gambar 2. Digram Pengelompokan well berdasarkan produksi

Penentukan dalam pengambilan keputusan untuk memprioritaskan sumur yang akan dilakukan test dilihat dari segi kebutuhan test sumur tiap bulan sehingga cara seperti ini dianggap lebih efektif dari sebelumnya karena dapat mencapai waktu yang efisien dan mengurangi kapasitas peralatan produksi. Pengelompokan Tes sumur setelah dilakukan Tiering System dapat dilihat pada Tabel 2 berikut ini. 
Tabel 2. Pengelompokkan Test Sumur di Area X

\begin{tabular}{|c|c|c|c|}
\hline Kategori & Jumlah Sumur & Test per bulan @ sumur & Total test \\
\hline Tier \#1 & 51 & 3 & 153 \\
\hline Tier \#2 & 112 & 2 & 224 \\
\hline Tier \#3 & 184 & 1 & 184 \\
\hline Tier \#4 & 216 & 1 & 216 \\
\hline \multicolumn{3}{|c|}{ Jumlah Total test Area X } & $\mathbf{7 7 7}$ \\
\hline
\end{tabular}

Setelah dikelompokan Tier masing masing, maka di peroleh total test secara keseluruhan adalah 777 kali dalam sebulan sedangkan kapasitas fasilitas untuk melakukan test sebelumnya adalah 960 kali dalam sebulan. Artinya setelah dilakukan Tier pada masing masing sumur tersebut terdapat sisa kapasitas test sebesar 183 kali test tiap bulan dari total kapasitas produksi sebelumnya.

Jika dilihat dari test yang dilakukan sebelum dilakukan Tier System dengan data sumur yang sama dalam sebulan, melakukan kegiatan testing masih kekurangan waktu dan kekurangan peralatan kapasitas produksi. Sehingga setelah dilakukan Tier System pada masing masing sumur, sehingga waktu yang digunakan dalam melakukan well testing akan lebih efisien dan sisa 183 sumur bisa digunakan untuk sumur special request.

Jumlah atau selisih yang diperoleh setelah dilakukan Tier tersebut akan dipergunakan untuk memenuhi kebutuhan test pada sumur sumur lain seperti kebutuhan sumur yang harus dilakukan test setelah pekerjaan kerja ulang sumur (work over) dan setelah pekerjaan stimulasi yang mana test sumur ini bertujuan melihat pengaruh dan hasil pekerjaan tersebut. Jika tidak ada sumur yang harus dilakukan test dari work over atau stimulasi, maka sisa dari waktu dan kapasitas peralatan produksi tersebut akan dipergunakan untuk melakukan test ulang terhadap sumur-sumur yang berada pada Tier \#3. Karena pada Tier \#3 dianggap memiliki produksi yang menengah dengan prioritas berdasarkan urutan besarnya produksi pada sumur. Sebanyak 112 sumur yang termasuk kedalam Tier \#3.

Berdasarkan data selisih atau sisa dari waktu dan kapasitas peralatan produksi masih mampu melakukan 1 kali test lagi pada semua sumur di Tier \#3. Karena jumlah test yang tersedia setelah schedule Tier bersisa adalah 183 kali test sedangkan sumur yang berada di Tier \#3 adalah 112. Sehingga masih terdapat sisa dari total keselurahan kapasitas test sebanyak 71 kali test yang tersisa dan ini adalah toleransi test dan untuk selanjutnya apabila keadaan normal schedule test bisa dilakukan dari awal lagi untuk bulan berikutnya.

\section{HASIL DAN PEMBAHASAN}

Dengan melakukan Tier pada masing masing sumur sebelum dilakukan well testing maka dapat meningkatkan kembali laju produksi suatu sumur dari produksi sebelumnya.

Tabel 3 menerangkan perbedaan produksi sebelum dan sesudah dilakukan tiering system. Setelah dilakukannya Tier System dalam melakukan well test, produksi di Area X meningkat. Jika dibandingkan antara sebelum dilakukan Tier System (1 Juli 2015-31 Agustus 2015) produksi hanya 25.806 BOPD sedangkan setelah dilakukan Tier System (1 September 2015 - 26 Oktober 2015) produksi di Area X menjadi 31.247 BOPD. Dengan demikian bisa disimpulkan terjadi peningkatan produksi. Hasil peningkatan produksi setelah dilakukan Tiering System dapat dilihat pada Gambar 4. 
Perhitungan keuntungan setelah dilakukannya Tier Sistem pada well test di Area X:

Dari data didapat:

\begin{tabular}{|c|c|}
\hline Produksi rata-rata Sebelum Tier system & $=25.806$ \\
\hline Produksi rata-rata Setelah Tier system & $=31.247$ \\
\hline Oil price & $=40$ \\
\hline
\end{tabular}

Peningkatan Produksi yang diperoleh

$=$ Prod setelah Tier system - Prod sebelum Tier sistem

$=31.247 \mathrm{BOPD}-25.806 \mathrm{BOPD}$

$=5.441 \mathrm{BOPD}$

Keuntungan setelah menggunakan Tier Sistem pada well test per bulan

$=$ Peningkatan Produksi x Oil Price

$=5.441 \mathrm{bbl} x \mathrm{US} \$ 40 / \mathrm{bbl}=\mathrm{US} \$ 217.621,75$

Berdasarkan perhitungan di atas menunjukkan bahwa setelah dilakukannya Tier Sistem menyebabkan produksi minyak meningkat. Sebelum dilakukannya Tier System produksi minyak untuk Area X hanya 25.806 BOPD sedangkan setelah dilakukan Tier System produksi meningkat menjadi 31247 BOPD.

Terjadi peningkatan produksi sebesar 5.441 BOPD antara sebelum dan sesudah dilakukannya Tier System. Sedangkan jika dihitung keuntungan yang didapatkan setelah dilakukannya Tier System adalah sebesar US\$217.621,75 per bulan lebih besar dibandingkan sebelum dilakukannya Tier System. Untuk lebih jelasnya bisa dilihat dari grafik pada gambar 3 berikut ini.

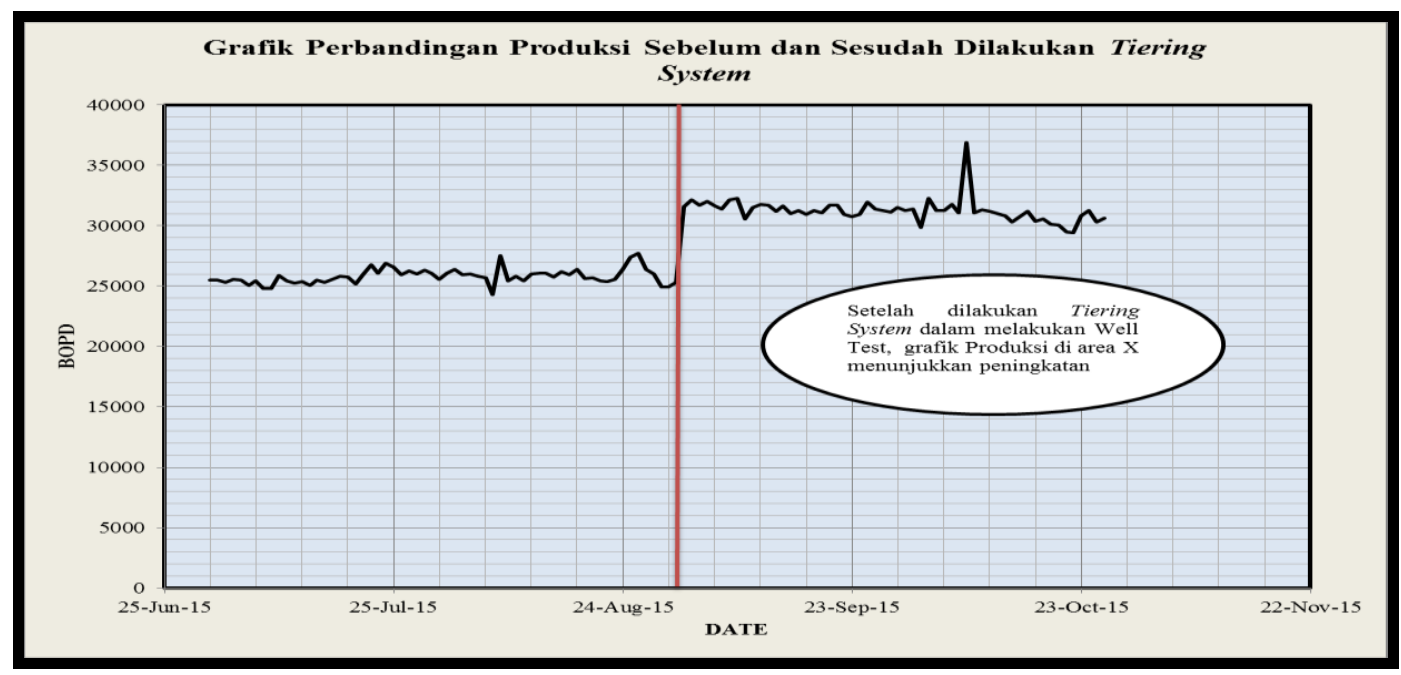

Gambar 3. Perbandingan Produksi Sebelum dan Sesudah Tiering System Dilakukan

Dari grafik diatas bisa terlihat bahwa pada bulan Juli 2015 dan Agustus 2015, produksi area hanya berkisar antara 25.000 barrel oil sampai 27.000 barrel oil sedangkan pada bulan Agustus 2015 dan Oktober jumlah produksi naik sekitar 30.000 barrel oil. 
Tabel 3. Perbandingan Produksi dalam satuan BOPD Area X sebelum dan sesudah diterapkan tiering system

\begin{tabular}{|c|c|c|c|c|c|c|c|c|}
\hline \multirow{2}{*}{ No. } & \multicolumn{4}{|c|}{ Sebelum Dilakukan Tiering System } & \multicolumn{4}{|c|}{ Setelah DilakukanTiering System } \\
\hline & Tanggal & Produksi & Tanggal & Produksi & Tanggal & Produksi & Tanggal & Produksi \\
\hline 1 & 1-Jul-15 & 25.516 & 1-Aug-15 & 26.054 & 1-Sep-15 & 31.542 & $1-$ Oct-15 & 31.368 \\
\hline 2 & 2-Jul-15 & 25.469 & 2-Aug-15 & 26.395 & $2-$ Sep-15 & 32.153 & $2-$ Oct-15 & 29.893 \\
\hline 3 & 3-Jul-15 & 25.308 & 3-Aug-15 & 25.967 & 3-Sep-15 & 31.690 & $3-$ Oct-15 & 32.280 \\
\hline 4 & 4-Jul-15 & 25.592 & 4-Aug-15 & 26.027 & 4-Sep-15 & 31.987 & 4-Oct-15 & 31.266 \\
\hline 5 & 5-Jul-15 & 25.474 & 5-Aug-15 & 25.817 & 5-Sep-15 & 31.659 & 5-Oct-15 & 31.277 \\
\hline 6 & 6-Jul-15 & 25.039 & 6-Aug-15 & 25.694 & 6-Sep-15 & 31.404 & 6-Oct-15 & 31.790 \\
\hline 7 & 7-Jul-15 & 25.410 & 7-Aug-15 & 24.283 & 7-Sep-15 & 32.145 & 7-Oct-15 & 31.035 \\
\hline 8 & 8-Jul-15 & 24.824 & 8-Aug-15 & 27.523 & 8-Sep-15 & 32.283 & 8 -Oct-15 & 36.894 \\
\hline 9 & 9-Jul-15 & 24.813 & 9-Aug-15 & 25.466 & 9-Sep-15 & 30.563 & 9-Oct-15 & 31.094 \\
\hline 10 & 10-Jul-15 & 25.889 & 10-Aug-15 & 25.804 & 10-Sep-15 & 31.525 & 10-Oct-15 & 31.339 \\
\hline 11 & 11-Jul-15 & 25.458 & 11-Aug-15 & 25.425 & 11-Sep-15 & 31.774 & 11-Oct-15 & 31.212 \\
\hline 12 & 12-Jul-15 & 25.226 & 12-Aug-15 & 26.035 & 12-Sep-15 & 31.723 & 12-Oct-15 & 31.006 \\
\hline 13 & 13-Jul-15 & 25.383 & 13-Aug-15 & 26.091 & 13-Sep-15 & 31.197 & 13-Oct-15 & 30.786 \\
\hline 14 & 14-Jul-15 & 25.079 & 14-Aug-15 & 26.081 & 14-Sep-15 & 31.648 & 14-Oct-15 & 30.299 \\
\hline 15 & 15-Jul-15 & 25.504 & 15-Aug-15 & 25.753 & 15-Sep-15 & 30.986 & 15 -Oct-15 & 30.733 \\
\hline 16 & 16-Jul-15 & 25.323 & 16-Aug-15 & 26.195 & 16-Sep-15 & 31.241 & 16-Oct-15 & 31.199 \\
\hline 17 & 17-Jul-15 & 25.558 & 17-Aug-15 & 25.926 & 17-Sep-15 & 30.932 & $17-$ Oct-15 & 30.352 \\
\hline 18 & 18-Jul-15 & 25.828 & 18-Aug-15 & 26.362 & 18-Sep-15 & 31.235 & 18-Oct-15 & 30.582 \\
\hline 19 & 19-Jul-15 & 25.768 & 19-Aug-15 & 25.652 & 19-Sep-15 & 31.096 & 19-Oct-15 & 30.104 \\
\hline 20 & 20-Jul-15 & 25.209 & 20-Aug-15 & 25.716 & 20-Sep-15 & 31.721 & 20 -Oct-15 & 30.034 \\
\hline
\end{tabular}


Tabel 3. Lanjutan - Perbandingan Produksi dalam satuan BOPD Area X sebelum dan sesudah diterapkan tiering system

\begin{tabular}{|c|c|c|c|c|c|c|c|c|}
\hline \multirow{2}{*}{ No. } & \multicolumn{4}{|c|}{ Sebelum Dilakukan Tiering System } & \multicolumn{4}{|c|}{ Setelah Dilakukan Tiering System } \\
\hline & Tanggal & Produksi & Tanggal & Produksi & Tanggal & Produksi & Tanggal & Produksi \\
\hline 21 & 21-Jul-15 & 26.007 & 21-Aug-15 & 25.463 & 21-Sep-15 & 31.717 & 21-Oct-15 & 29.488 \\
\hline 22 & 22-Jul-15 & 26.795 & 22-Aug-15 & 25.377 & 22-Sep-15 & 30.945 & 22-Oct-15 & 29.441 \\
\hline 23 & 23-Jul-15 & 26.084 & 23-Aug-15 & 25.558 & 23-Sep-15 & 30.774 & 23-Oct-15 & 30.794 \\
\hline 24 & 24-Jul-15 & 26.921 & 24-Aug-15 & 26.413 & 24-Sep-15 & 30.946 & 24-Oct-15 & 31.260 \\
\hline 25 & 25-Jul-15 & 26.581 & 25-Aug-15 & 27.416 & 25-Sep-15 & 31.967 & $25-O c t-15$ & 30.323 \\
\hline 26 & 26-Jul-15 & 25.950 & 26-Aug-15 & 27.693 & 26-Sep-15 & 31.390 & 26-Oct-15 & 30.606 \\
\hline 27 & 27-Jul-15 & 26.258 & 27-Aug-15 & 26.407 & 27-Sep-15 & 31.278 & & \\
\hline-28 & 28-Jul-15 & 26.008 & 28-Aug-15 & 25.978 & 28-Sep-15 & 31.121 & & \\
\hline 29 & 29-Jul-15 & 26.326 & 29-Aug-15 & 24.956 & 29-Sep-15 & 31.478 & & \\
\hline 30 & 30-Jul-15 & 26.061 & 30-Aug-15 & 24.901 & 30-Sep-15 & 31.242 & & \\
\hline 31 & 31-Jul-15 & 25.570 & 31-Aug-15 & 25.326 & - & - & & \\
\hline
\end{tabular}




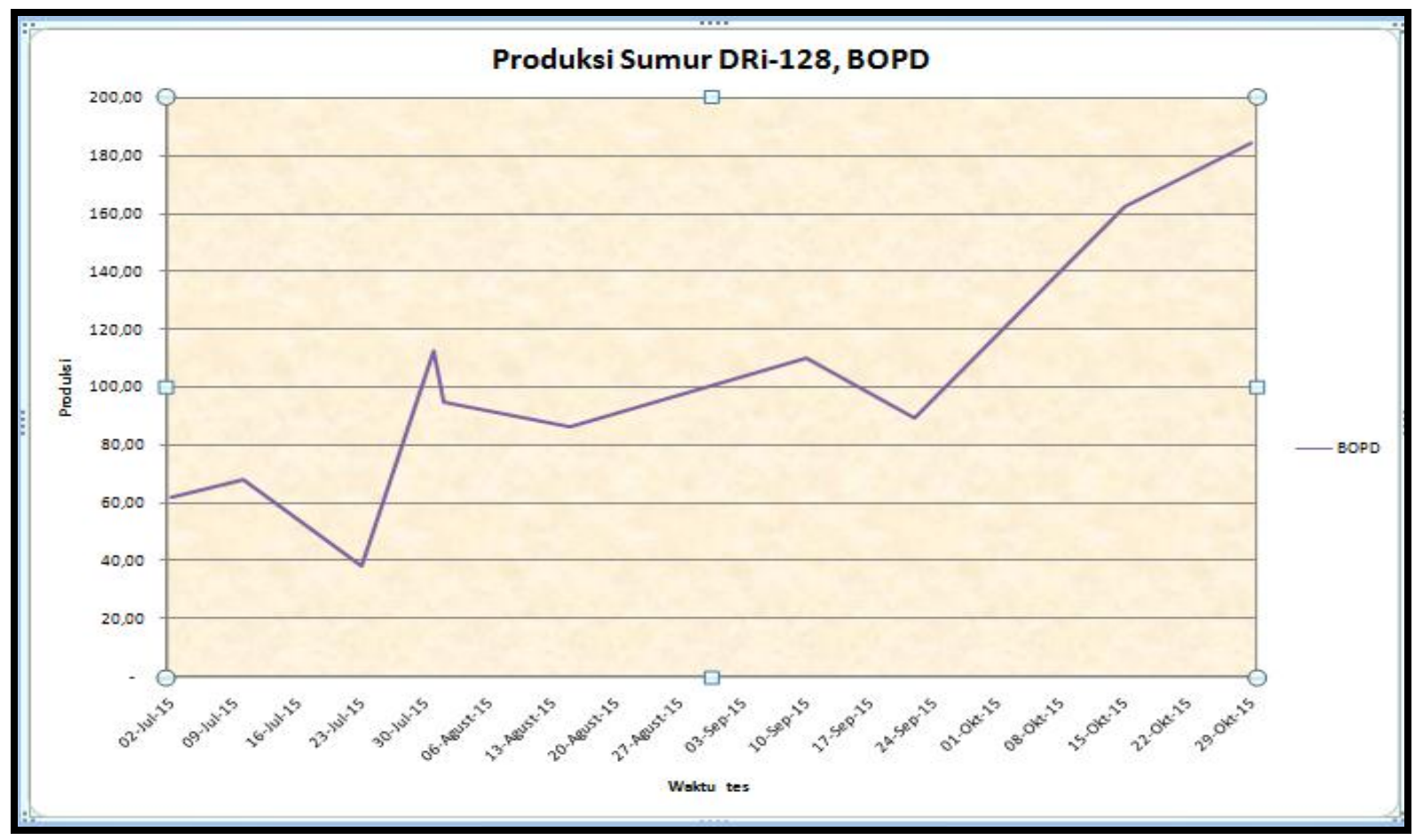

Gambar 4. Grafik Produksi Sumur pada Area X Lapangan Y

\section{KESIMPULAN}

Hasil yang diperoleh dari penelitian ini dapat disimpulkan sbegai berikut:

1. Sebelum dilakukannya Tiering System, dari 563 sumur yang ada di Area X dilakukan 1126 kali test untuk setiap bulannya (tes 1 sumur2 kali perbulan). Sedangkan di Area X hanya tersedia 4 Tank Gauging yang mana kapasitasnya 240 test/tank gauging. Jadi 960 kali bisa dilakukan test untuk Area X dan 116 kali test tidak mendapatkan jadwal test. Maka untuk itu dilakukan pengelompokkan sumur berdasarkan produksi.

2. Setelah dilakukan Tiering System (pengelompokkan) terhadap sumur-sumur di area $X$ berdasarkan produksi dari tertinggi ke terendah maka diperoleh peningkatan produksi sebesar $5441 \mathrm{bbl}$ per hari, sedangkan keuntungan financialnya sebesar 217.621,75 US\$. Perhitungan keekonomiannya dihitung berdasarkan harga minyak pada bulan November 2015 yaitu 40 US\$ per barrel.

\section{DAFTAR PUSTAKA}

Rubiandini, Rudi \& Syihab, Zuher., 2002. Reservoir-Production Performance Analisys and Evaluation (basic). PT. Caltex Pacific Indonesia-Sumatra

Santoso, Heru. 2001. Practical Petroleum Engineering. Duri-Riau

Sutachyar, SST, Achyar. 2009. BHP, BHT and Sonolog. Pusdiklat Migas Cepu, Jawa Tengah

Human Resources Sumatra Operation, 2012. Production Operation modul 6B. PT. Chevron Pacific Indonesia

Human Resources Sumatra Operation, 2012. Production Operation modul 4B. PT. Chevron Pacific Indonesia 
Amin, Mustaghfirin, 2013, Teknik Produksi Migas Semester 3. Kementrian Pendidikan dan Kebudayaan, Jakarta.

Juniawan, 2011, Re-Optimasi Pompa Sucker Rod Berdasarkan Analisa Sonolog”, UPN , Yogyakarta, 